\title{
Exploring the asymmetric coding of autobenefactive in Lithuanian and beyond
}

\author{
Vladimir Panov
}

Vilnius University

In this paper, I investigate a group of semantically close functions marked by the Reflexive marker in Lithuanian, which I address as autobenefactive. I provide a classification of these functions and then turn to a marking asymmetry which is characteristic of them, namely the tendency to occur in perfective contexts and not to occur in progressive contexts. On the basis of a questionnaire, I show that this tendency indeed exists, although different verbs are involved to different degrees, and we are presumably witnessing an ongoing grammaticalization process. I then compare the Lithuanian marking asymmetry to a phenomenon in Georgian, in which the use of 'subjective version' exhibits a similar kind of asymmetry with some groups of verbs. In the concluding section, I propose a typological explanation of the observed asymmetry, hypothesizing that the markers of both languages function in a way parallel to so-called 'bounders'-telicizers with primary spatial meanings.

Keywords: reflexive, middle, autobenefactive, aspect, Lithuanian, Georgian

\section{Introduction ${ }^{1}$}

The research idea for this paper was originally driven by one observation on everyday Lithuanian speech. When speaking of buying things in the past, one usually (in fact, obligatorily) uses the Reflexive ${ }^{2}$ marker si when one buys things for oneself (1):

\footnotetext{
${ }^{1}$ I express my gratitude to my Lithuanian informants, to the anonymous reviewers, and to the members of the research project The Baltic Verb: Grams, Categories and Domains for their feedback. This research has received funding from the European Social Fund (project No. 09.3.3-LMT-K-712-01-0071) under grant agreement with the Research Council of Lithuania (LMTLT).

${ }^{2}$ I follow Croft (2001) in capitalizing language-particular categories, as opposed to typological comparative concepts, which are not capitalized.
} 
(1) $A \check{s}$

I.NOM nu-si-pirk-au

PVB-REFL-buy-1SG.PST obuoli-ur.

apple-GEN.PL

'I bought some apples for myself.'

In contrast, when speaking of the ongoing process of buying (2), one normally doesn't use the Reflexive (a), and its use would be very awkward if possible at all (b):

(2) (a) $A \check{s}$

perk-u

obuoli-us. ${ }^{3}$

I.NOM buy-1sG.PRS apple-ACC.PL

'I am buying apples for myself.'

(b) ${ }^{*} A \check{s}$

$$
\text { perk-uo-si obuoli-us. }
$$

I.NOM bUy-1SG.PRS-REFL

apple-AcC.PL

'I am buying apples for myself.'

As will be shown, this kind of asymmetry extends beyond the Lithuanian verb pirkti 'buy' and also beyond the Lithuanian language. Hence the goal of the paper: step-by-step, I will explore the mechanisms behind this marking asymmetry in Lithuanian. In doing so, I will invoke languageinternal, theoretical (conceptual-semantic), and typological perspectives.

In section 2, I analyse the domain of the indirect middle/reflexive in Lithuanian. I propose an internal classification based on semantic and formal criteria (2.1), and briefly discuss its typological and areal context (2.2). In section 3 , I address the main question of the paper, namely, the coding asymmetry presented in the introduction. Section 4 is dedicated to the search for an explanation of the asymmetry in question; it discusses methodological issues (4.1) and the cross-linguistic aspect of the problem (4.2). I summarize the results in the Conclusion (5). The Appendix presents the questionnaire used for the present study.

\footnotetext{
${ }^{3}$ The examples (1) and (2a), apart from the TAM differences and the presence/absence of a reflexive marker, also differ with respect to the case marking of the object. In these examples, aspect also correlates with the type of definiteness and quantification. In telic contexts such as (1), indefinite quantity is marked by the partitive Genitive in Lithuanian. By contrast, in progressive contexts (with verbs not denoting states) the object is normally the incremental theme (an entity incrementally affected by the action). This role is marked by the Accusative case. In (2a), the object of the verb pirkti 'buy'-obuolius 'apples'-is interpreted (in a somewhat generalized manner) as the incremental theme.
} 


\section{Indirect middle, indirect reflexive, and autobenefactive}

\subsection{Lithuanian}

Let us continue with the example of the Lithuanian verb pirkti 'buy'. As shown in (1) and (2), it is often used with the Reflexive marker si. Its use is close to obligatory (in some TAM forms) in cases where the buyer and the person for whose benefit the act of buying is carried out are one and the same person. The condition of coreference of agent and beneficiary is the only one that triggers the use of si in such cases, and it is used with all three persons:

(3) (a) Aš nu-si-pirk-au obuoli-u.

I.NOM PVB-REFL-buy-PST.1SG apple-GEN.PL

'I bought some apples (for myself).'

(b) $\mathrm{Tu}$ nu-si-pirk-ai obuoli-ų.

you.NOM PVB-REFL-buy-PST.2SG apple-GEN.PL

'You bought some apples (for yourself).'

(c) fie nu-si-pirk-o obuoli-ų.

they PVB-REFL-buy-PST.3 apple-GEN.PL

'They bought some apples (for themselves).'

The absence of si in any of these cases results in a different reading of each sentence, namely, the beneficiary and the agent are inherently distinct:

(4) Aš nu-pirk-au obuoli-ų.

I.NOM PVB-buy-PST.1SG apple-GEN.PL

'I bought some apples (for someone else).'

In cases like (4), the beneficiary can be implicit or explicit (expressed by a full pronoun or a noun phrase). By contrast, whenever the Reflexive marker is present as in (3), the addition of a beneficiary argument noncoreferential with the agent is blocked:

(5) ${ }^{*} A \check{s}$

I.NOM

nu-si-pirk-au

PVB-REFL-buy-PST.1SG

'I bought you some apples.' tau obuoli-ų.

yOu.SG.DAT apple-GEN.PL

Summing up, in Lithuanian, the coreference of the agent-subject and the beneficiary is obligatorily marked by the Reflexive marker, at least in certain TAM forms. The converse is also true: non-coreferential agent-subject and 
beneficiary cannot induce Reflexive marking. Following Kulikov (2013), I call this meaning autobenefactive.

In Lithuanian and cross-linguistically, the autobenefactive belongs to a broader domain which is best referred to as the continuum between the indirect reflexive and the indirect middle. These are terms used by Kemmer (1993), but terminology in this domain is not quite established. In Kemmer's version, the crucial difference between the middle and the reflexive is the degree of naturalness of the coreferentiality. Break an arm is not naturally reflexive-one can break one's own arm as easily as someone else's arm. In contrast, the situations of washing or buying normally presuppose that the object-either direct or indirect-coincides with the agent-subject. Kemmer applies the label reflexive to the former kind of situations, whereas the label middle is reserved for the latter.

Cross-linguistically, however, more semantic factors are at play in reflexive-middle marking. Another dimension is the type of coreferentiality of the agent-subject and the object. While the agents of a reflexive and middle constructions are normally human beings or at least animate beings, their 'self' may be interpreted by a language in different ways: as the motor centre, as the body, as part of the body, as the personality and as the body-soul composite. Along this axis, situations like 'see oneself in the mirror' or 'cut one's finger' may behave differently in terms of reflexive/middle marking cross-linguistically and language-internally.

The third axis relates to the issue of transitivity reflected in the very terms direct/indirect middle/reflexive. Transitivity can best be viewed as a multifactorial phenomenon combining different semantic parameters that tend to co-occur. The more parameters show up together, the more transitive a construction is; conversely, the fewer parameters converge, the less transitive a construction is. This 'prototype' approach is applied in the classical papers by Hopper \& Thompson (1980) and Tsunoda (1981) and elaborated in subsequent work. Different languages have different transitivity marking strategies: the same situations can be marked as transitive or intransitive, and different languages exhibit various kinds of transitivity splits, e.g., TAM-splits.

Lithuanian does not formally distinguish between transitive (direct) and intransitive (indirect) reflexive/middle marking on the verb form (in 
Kemmer's terminology). ${ }^{4}$ So how can one distinguish between direct/ transitive and indirect/intransitive Reflexives? Does this distinction make sense at all? The distinction between the direct and the indirect Reflexive is primarily semantic, i.e., these are two groups of functions expressed by the same marker which can be distinguished for the convenience of linguists and grammar readers. However, there are still some formal distinctions between the two groups that are not immediately visible. I suggest three definitions, which may apply to Reflexive-marked constructions either jointly or separately and thus allow us to classify each construction as a direct or an indirect one.

(i) A Reflexive construction is a direct one if, when the condition of subject-agent and object coreferentiality is changed, the Reflexive marker obligatorily disappears, and the new object is in the Accusative case (6).

(6) (a) Ǎ́ už-si-registrav-au I PVB-REFL-register-PST.1SG 'I registered (myself) for an event.'
I.NOM PVB-register-PST.1SG
'I registered you for an/the event.'
you.sG.Acc event-SG.LOC

If the aforementioned twofold condition is not satisfied, then the construction is to be interpreted as an Indirect Reflexive construction. In this case, the new object is normally in the Dative Case form which can, however, have different functions such as benefactive (7) or external possessor (8):

(7) (a) $A \check{s}$
I.NOM
pa-si-èmi-au
vandens.
'I got some water for myself.'
water.GEN.SG

(b) $A \check{s}$

pa-èmi-au

I.NOM

PVB-take-PST.1SG

'I got some water for you.' rengin-yje.

event-SG.LOC

renginyje. tau

you.SG.DAT vandens.

water.GEN.SG

\footnotetext{
${ }^{4}$ Naturally, this only applies to 'light' (bound) markers. 'Heavy' (non-bound) markers do distinguish between accusative forms (matau save veidrodyje 'I see myself in a mirror') and dative forms (perku mašinq sau 'I am buying myself a car'). More about the 'light' and 'heavy' Reflexive forms in Lithuanian see Holvoet (2020).
} 

I.NOM
$u \check{z}-s i-d e j j-a u$
kepur-e.
I.NOM PVB-REFL-put_on-PST.1SG
cap-ACC.SG

'I put my cap on.'

(b) $A \check{s}$

\section{$u \check{z}-d e j-a u$}

I.NOM PVB-put_on-PST.1SG

vaik-ui
child-DAT.sG

kepur-e.

'I put the child's cap on.'

cap-ACC.sG

Describing Lithuanian, I will call contexts like (7) Strong Autobenefactive, following partly Kulikov (2013) and Holvoet (2020). These are contrasted to Weak Autobenefactives (see below). I preserve Geniušienè's term Reflexive Recipient for contexts like (8a), capitalizing it as a language-particular descriptive category of Lithuanian.

Their very close relatives are 'possessive reflexives' (in Geniušienè's terminology) as in (9), which have the same formal properties as Reflexive Recipient constructions.

(9) Jis su-si-lauž- $\dot{e}$ rank-a. he.NOM PVB-REFL-break-PST.3

hand-ACC.SG

'He broke his hand.'

(ii) If a Reflexive construction contains an object in the Accusative or partitive/negative Genitive Case, then it is an indirect reflexive/middle construction. Actually, both examples (7b) and (8b) contain such objects. In some cases, Reflexive forms that otherwise seem identical can differ in meaning depending on the presence of a free direct object. In (10), the Reflexive is clearly a direct one, as it can be substituted by a free noun phrase. By contrast, in (11) we are dealing with an Indirect Reflexive. In this semantic type, the Reflexive marker refers to the recipient argument, as Geniušiene $(1987,128)$ argues.

(10) (a) Aš ap-si-rengi-au.

I.NOM PVB-REFL-dress-PST.1SG

'I dressed myself.'
(b) $A \check{s}$
ap-rengi-au
vaik-ą.
I.NOM PVB-dress-PST.1SG
child-ACC.SG
'I dressed the child.'

(11) Aš ap-si-rengi-au palt-ą.

I.NOM PVB-REFL-dress-PST.1SG coat-ACC.SG

'I put my coat on.' 
(iii) Reflexive-marked constructions in which the Reflexive marker cannot be replaced with a noun phrase or a full stressed pronominal phrase can also be considered Indirect Reflexive constructions. In such cases, the Reflexive marker provides a 'weak' reference to the subject-agent argument. It indicates that the agent somehow, although less immediately than in typical Strong Autobenefactives, benefits from the action, or is affected by the action in another way. I will call this group of constructions Weak Autobenefactives. Unlike the Strong Autobenefactive, it is often non-obligatory, and the Reflexive marker can be omitted without major consequences in the reading of a sentence.

Weak Autobenefactives can be subdivided into several formally distinguishable groups, according to the verb's valence and semantics. The first group includes verbs with more than one argument, the non-subject being an argument in the Dative or a prepositional phrase. Normally, verbs of talking and communication belong to this class, and the non-agent indirect argument refers to the second speech participant, whose agency is perceived as not much lower than that of the agent. These contexts are semantically close to reciprocals but are formally not identical to them (12):

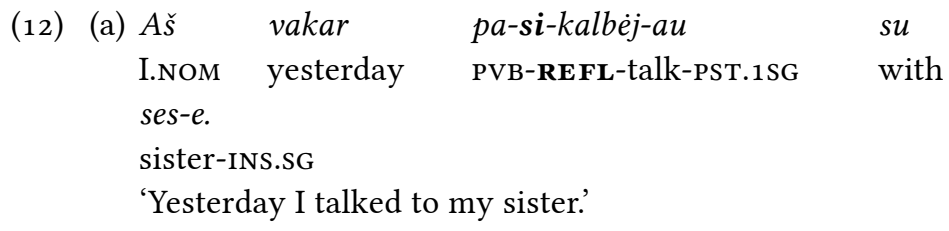
(b) Aš pa-si-pasako-si-u jam.
I.NOM PVB-REFL-tell-FUT-1SG he.DAT
'I will tell him (my story).'

Semantically, Weak Autobenefactive communication constructions are distinct from reciprocals in that in the former case, one speech participant is the prominent one, to whom attention is drawn, whereas in the latter case both participants are viewed as equal.

In the second formally definable group, the verb has only one subject argument:
(13) $A \check{s}$
buv-au
pa-si-vaikščio-ti
mišk-e.
I.NOM
be-PST.1SG
PVB-REFL-walk-INF
forest-SG.LOC

'I went for a walk to the forest.' 
In (13) the action of going for a walk is conceptualized as healthy or pleasant for the walker. Finally, the same function can be posited for transitive reflexive perception verbs such as pa-si-klausyti 'listen to', $p a-$ si-žiūrèti 'watch', pa-si-grožèti 'marvel at', where Non-Reflexive Dative paraphrase is also hardly possible (14b):
(14)
(a) $A \check{s}$
pa-si-žiūrèj-au
"Viking-us".
I.NOM PVB-RE FL-watch-PST.1SG
'I watched "Vikings".
Viking-PL.ACC
(b) * $A \check{s}$
$p a-z ̌ i z \bar{r} r \dot{j}-a u$
I.NOM PVB-watch-PST.1SG
'I watched "Vikings” for you.'
tau
you.DAT Viking-PL.ACC

It is hard to imagine watching a TV show for someone else. However, one can imagine a situation in which one asks a friend to watch an episode of Vikings (and then retell its plot) because s/he is busy but wants to keep track of the story. This relation cannot be rendered by a Dative complement.

Let us summarize the proposed classification. Although Lithuanian does not formally distinguish between the transitive and the intransitive reflexive/middle by means of verbal morphology (there is only one Reflexive marker), one can distinguish between different constructions along the direct > indirect reflexive/middle scale on the basis of syntactic and semantic criteria. First, one can distinguish between the (i) Direct Reflexive (ex. 6), (ii) Indirect Reflexive (ex. 7b, 8b, 11-14). Second, in the Indirect domain, one can distinguish between the (a) Strong Autobenefactive (7), (b) Weak Autobenefactive (ex. 12-14), (c) Possessive Reflexive ('grooming' \& 'injury' verbs, ex. 9), (d) Reflexive Recipient ('dressing' verbs, ex. 11).

The classification provided above has proven useful in explaining asymmetries provided in the beginning of this paper such as in ex. (2).

\subsection{The cross-linguistic dimension and the context of the region}

The morphological marking of indirect reflexive and middle is well attested cross-linguistically in different genera and regions, e.g. in Japhug Rgyalrong, Kiranti, Sino-Tibetan (Jacques 2015), in various Bantu languages (Dom, Kulikov \& Bostoen 2016), Georgian (Boeder 1968; Harris 1981; Gurevich 2006). In Indo-European, it is typical of the older languages 
that had preserved the Proto-Indo-European inflectional middle voice morphology, such as Ancient Greek (Allan 2003; Willi 2018) and Sanskrit (Kulikov 2013). However, in its contemporary regional and genealogical context, Lithuanian is unique with respect to the extent to which this domain is central to its grammar. ${ }^{5}$

\section{Autobenefactive in Lithuanian: coding asymmetries}

\subsection{Pirkti 'buy'}

Let us take a look at the examples from the beginning of this paper again:
(15) (a) $A \check{s}$
nu-si-pirk-au
obuoli-u.
I.NOM PVB-REFL-buy-1SG.PST
apple-GEN.PL
'I bought some apples for myself.'
(b) Ǎs perk-u obuoli-us.
I.NOM buy-1SG.PRS apple-ACC.PL
'I am buying apples for myself.'
(c) ${ }^{*} A \check{s}$ perk-uo-si obuoli-us.
I.NOM buy-PRS.1SG-REFL apple-ACC.PL
'I am buying apples for myself'

Here, we are clearly dealing with the function of the Reflexive marker I previously defined as Strong Autobenefactive. This can be seen if one applies our test:

(16) (a) $A \check{s}$
I.NOM
'I bought apples for myself'
apple-GEN.PL

nu-si-pirk-au

obuoli-u

(b) $A \check{s}$

$$
n u-{ }^{*} \text { si-pirk-au }
$$

jam

I.NOM

PVB-REFL-buy-PST.1SG.

he.DAT

obuoli-y

'I bought apples for myself for him'

Our main observation here is that the use of the Reflexive marker is blocked in the Present Tense, although it is obligatory in the Past Tense whenever the agent and the beneficiary are coreferential. Therefore, we

\footnotetext{
${ }^{5}$ This is true with regard to the standard languages. However, as Paweł Brudzyński (personal communication) reports, colloquial Polish makes an extensive use of the abbreviated form of the dative Reflexive Pronoun se < sobie in indirect middle/reflexive functions.
} 
are dealing with a marking asymmetry. There is an immediate temptation to claim that the Strong Autobenefactive Reflexive is used in the Past Tense and is blocked in the Present, that is, there seems to be a tense-based coding asymmetry. However, let us check more constructions and find out where the Strong Autobenefactive Reflexive is used or blocked with the verb pirkti 'buy' (again, under the condition of agent-beneficiary coreference). Here is the picture we get.

(17)
(a) Čia
$a \check{s}$
kasdien
nu-si-perk-u
Here I.NOM every_day
PVB-RE FL-buy-PRS.1SG
obuoli-u.
apple-GEN.PL

'Here I buy apples every day.'

(b) $A \check{s}$

tuoj

nu-si-pirk-si-u

obuoli-u.

I.NOM presently PVB-REFL-buy-FUT-1SG

apple-GEN.PL

'I will now buy some apples.'

(c) $A \check{s}$

nori-u

$n u$-si-pirk-ti

obuoli-ų.

I.NOM

want-PRS.1SG

PVB-REFL-buy-INF

apple-GEN.PL

'I want to buy some apples.'

(d) Ei-k nu-si-pirk go-IMP PVB-REFL-buy.IMP

obuoli-ų.

apple-GEN.PL

'Go and buy some apples.'

(e) Čia

$\begin{array}{ll}a \check{s} & k a s d i e n \\ \text { I.NOM } & \text { every day }\end{array}$

nu-si-pirk-dav-au

here I.NOM

every_day

PVB-RE FL-buy-HAB-PST.1SG

obuoli-u.

apple-GEN.PL

'Here I used to buy apples every day.'

(18)
(a) $\mathrm{Kai} \quad a \check{s}$
when I.NOM
*pirk-au-si
obuoli-us,
$t u$
pa-skambin-ai.
buy-PST.1SG-REFL
apple-AcC.PL you
PVB-call-PST.2SG
'While I was buying apples, you called.'

(b) $\mathrm{Ka}$

$a \check{s}$

when I.NOM

*pirk-si-uo-s

obuoli-us,

pa-skambin-k.

buy-FUT-1SG-REFL

apple-Acc.PL

PVB-call-IMP

'When I'll be buying apples, call me.'

(c) ${ }^{*}$ Pir-ki-s

obuol-ius

tik

buy-IMP-REFL

apple-AcC.PL

only

turg-uje.

'Buy apples only at the market.'

market-SG.LOC 
(d) $A \check{s}$

planuoj-u

*pirk-ti-s

obuoli-us

tik

I.NOM plan-PRS.1SG

bUY-INF-REFL

apple-Acc.PL

only

turg-uje.

market-SG.LOC

'My plan is to buy apples only at the market.'

The first obvious observation one can make is that whenever the Reflexive marker is used, it co-occurs with a preverb. As is widely known, preverbs telicize verbs in Lithuanian (e.g. Arkadiev 2011), and, more widely, influence their actionality characteristics. The degree of grammaticalization of the preverb-based telicity does not reach that of Slavic languages, i.e., does not result in a clear-cut binary aspectual system, being, however, close enough to the latter type.

Therefore, the Strong Autobenefactive Reflexive of the verb pirkti is only possible (and obligatory) in telic contexts, where the telicity is marked by the preverb $n u$ - 'down'). Besides the telic Past, it occurs in the habitual Present (17a) and the habitual Past (17e), but not in the progressive Present $(15 \mathrm{c})$ and the progressive Past (18a), in the telic Future (17b), the Infinitive $(17 \mathrm{c})$, and the Imperative $(17 \mathrm{~d})$, but not in the cases when the same inflectional forms have progressive readings (18b-d).

\subsection{Other verbs}

Given that there is no morphological differentiation between direct and indirect reflexive/middle forms in Lithuanian-all are expressed by the Reflexive marker-there is no obvious way of conducting a corpus-based analysis, at least, starting research with one. Therefore my primary data-a list of recurrent indirect middle/reflexive verbs-have been collected during a short-term 'participant observation' study. ${ }^{6}$ I established

\footnotetext{
${ }^{6}$ The participant observation method is the main method in social anthropology, but it is less accepted as legitimate in linguistics. Field linguists usually rely on questionnaires and spontaneous speech recordings. However, there are types of tasks for which participant observation appears a suitable method. So is our case of indirect reflexive/middle verbs. These verbs are not very frequent forms in speech, therefore, establishing frequently used verbs of these types in traditional ways would require many hours of recording of spontaneous speech and its transcription. However, if the goal is only to establish relevant lexical units, participant observation is a legitimate shortcut. During this study, whenever it was possible, I regularly made notes when participating myself in everyday speech situations for a month-long period. I registered indirect reflexive/middle forms repeatedly used by my speech partners, all native speakers. This resulted in a list of verbs that cannot be treated as accurately representing the actual frequency distributions in the colloquial speech; however, there is no doubt that this list can be used as a foundation for a preliminary study of the verbs of these classes.
} 
44 commonly used lexical items, excluding variants without or with preverbs with no significant difference in meaning, which are used with the Reflexive marker in indirect middle/reflexive functions. After identifying indirect middle/reflexive verbs commonly used in colloquial speech, I asked five native speakers of Lithuanian of different ages and genders living in Vilnius for an extended period to fill in a questionnaire, asking them whether they would use each verb in a present progressive context (in constructed sentences). ${ }^{7}$ There were three possible answers: 'I would definitely say this', 'This is not very natural' and 'I would never say this'. The questionnaire with the results is provided in the Appendix. If a certain answer was marked as possible by at least one informant, I provide the number of informants $(<5)$ who have chosen this particular answer.

The results of the participant observation and questionnaire-based investigation can be summarized as follows. Although most speakers report that they would use most verbs in their reflexive forms in present progressive contexts, there are a few constructions which are consistently ruled out by all or most speakers. Here, the convergence of the speaker's intuitions is very high. These include pirkti duona 'to buy bread', imti puodukq iš spintos 'to take a cup from the cupboard', žiūrèti filma 'to watch a movie', užmiršti tas laimingas dienas 'to forget these happy days', jungti kolega prie videokonferencijos 'to make a colleague join the online conference', vaikščioti po parka 'go for a walk in a park', eiti per parka 'walk across a park', skaityti knyga 'read a book'.

The second group includes constructions on which speakers demonstrate a large extent of hesitation and non-convergence of answers. Among such constructions are the 'cooking' constructions gaminti pietus 'cook lunch' and ruošti pietus 'prepare lunch', virti kiaušinius 'boil eggs', kepti kiaušiniene 'fry eggs', where different speakers' intuitions vary along the whole scale of possible answers from absolute allowance to an absolute ban. For the rest of the constructions of the list, my informants demonstrate highly divergent results ranging from 'I would definitely say that' to 'This is not

\footnotetext{
${ }^{7}$ I did not check other atelic contexts, which I investigated above for the verb pirkti 'buy'. Filling such a questionnaire would require too much time resources from my informants. However, testing three more verbs - imti 'take', žiūreti 'watch', and skaityti 'read'-has shown that the inability to occur as a Reflexive in the continuous Present entails the impossibility of Reflexive marking in other atelic contexts as well.
} 
very natural' in evaluating certain forms, and different speakers rule out various amounts of Reflexive Present progressive constructions.

Both groups are heterogeneous in terms of the classification of indirect middle/reflexive forms of Lithuanian proposed in Section 2.1.

All speakers agree on their intuitions about the constructions with body-position change verbs stoti-s 'stand up', sèsti-s 'sit down', gulti-s 'lay down'. These verbs fall into the category of Weak Autobenefactive of my classification. All speakers allow Reflexive marking in the continuous Present in the versions of the verbs without a preverb, but their answers diverge when a form with preverb is proposed. For instance, my informants disagree on the possibility of the construction Aš at-si-stoju iš lovos 'I am standing up (PVB-REFL-stand_up-PRS.1SG) from a bed'.

A large and open group of verbs, of which only a handful are present in my survey, are the verbs with the delimitative $p a$-such as $\boldsymbol{p a}$-si-vaikščioti 'go for a walk', pa-si-žiūrèti 'watch' or pa-si-skaityti 'read'. This is a productive model in Lithuanian, and it appears that whenever the animate referent of the subject carries out the action for him/herself, which is normally the case, a weak autobenefactive Reflexive is possible (although not obligatory). Not surprisingly, both the Reflexive marker and the preverb are consistently dropped in progressive contexts.

Finally, I have found very few examples of present progressive uses of any verb from my questionnaire the National Corpus of Lithuanian. ${ }^{8}$ This may be due to various reasons. First, it might be the case that present progressive uses of the majority of indirect middle/reflexive verbs do not occur in practice, although such uses are usually not perceived by native speakers as ungrammatical. A second option is the limited volume of texts contained in the corpus. Finally, there is a possibility that the corpus data are skewed in favor of normative uses. Nevertheless, I have not been able to find any prescriptive rules regarding the use of such forms on the website of the State Commission of the Lithuanian Language. ${ }^{9}$

\footnotetext{
${ }^{8}$ http://tekstynas.vdu.lt/tekstynas/index.jsp

${ }^{9}$ http://www.vlkk.lt/en/
} 


\section{An attempt at an explanation}

\subsection{Language-particular vs. universal}

The participant observation and questionnaire investigation results presented in the previous section allow us to conclude that the use of indirect middle/reflexive forms demonstrate a bias toward incompatibility with progressive contexts. However, given that the answers provided by Lithuanian native speakers exhibit a large extent of non-convergence, one can conclude that we are dealing only with a tendency, not with a rigid rule. This means that we are most probably witnessing an ongoing process in its evolution, with various verbs and constructions involved to a different extent. This process can lead to various and hardly predictable results in the future.

Given that we are dealing with a weak tendency in the asymmetry of coding, one can ask a why-question: what are the reasons for a seemingly restricted compatibility of indirect reflexive/middle verbs with present progressive contexts? In this piece of research, I investigate one single language-Lithuanian. Why-questions on the structural idiosyncrasies of particular languages are a controversial issue: after all, language-particular structures are results of historical accident. In other words, particular languages are the way they are because they happen to have come to be this way. The tendency observed in the present study may easily be this kind of historical idiosyncrasy. In the research in linguistic typology and usage-based linguistics, there had always been a tacit assumption, which was recently made more explicit (Schmidtke-Bode et al., eds., 2019), to the effect that explanation is only possible for cross-linguistic tendencies (universals), not language-particular structures..$^{10}$ By only looking at cross-linguistic regularities, one can express enlightening hypotheses about their motivation, whereas language-particular data are to a large extent accidental and thus insufficient for building an explanatory theory of language. The opposite is not true: language-particular structures can reflect universal tendencies, but this is not necessary.

Does this mean that in our case, which is language-particular, one should give up any attempt of explanation? I do not think so for two

\footnotetext{
${ }^{10}$ This is also the core argument of most recent work by Martin Haspelmath (2010; 2018 etc.).
} 
reasons. First, in Lithuanian, we are dealing with a systematic, although weak, coding asymmetry, which involves verbs of a particular semantic rather than formally distinguished class: it is only one particular group of Reflexive-marked verbs which exhibits the described asymmetric behavior. Semantics are widely assumed to be more universal than language-particular formal categories (Croft 2001); this makes our observed phenomenon less dependent on language-particular formal idiosyncrasies and gives it a universal dimension. Secondly, one can preliminarily claim that the coding tendency described here for Lithuanian is not unique to this language (see below), although much more cross-linguistic research is needed.

\subsection{Autobenefactive and TAM beyond Lithuanian}

In the present stage, I have found at least one language exhibiting a coding asymmetry somewhat parallel to that of Lithuanian, which has been described at least to some extent.

Georgian is well known for its aspect marking which is strikingly similar to that of Slavic or Lithuanian (Tomelleri 2009; Tomelleri \& Gäumann 2015). Georgian, as well as the other Kartvelian languages, uses spatial preverbs as telicizers, and the vast majority of its verbs exhibit PFV-IPFV aspectual pairs in the 'Slavic' spirit. Another remarkable parallel between Georgian and East and West Slavic, also shared with its neighboring Ossetic (East Iranian), is that the present tense forms with telicizing preverbs have future tense reference. On the other hand, very much like Bulgarian and Macedonian, Georgian exhibits a complex semantic interplay between the preverb-based derivational aspect and the inflectional aspect, the latter being manifested by an opposition between the 'present' and the 'aoristic' stems and two sets of inflectional paradigms in the past tense.

Another prominent structural feature of Georgian and Kartvelian in general is the morphological category traditionally addressed as version (a Latinate translation of the Georgian term kceva). Formally, the markers of version are manifest as a set of pre-radical vowels $(-a-,-i-,-u-,-e-)$. All the version markers are remarkably polysemous; however, the functional domain of version can be roughly defined as valence-changing or, more generally, as the degree and type of affectedness of various participants (Gurevich 2006, 121). 
Of our interest here is the co-called Subject(ive) Version - $i$-, which is used whenever it is the subject of the sentence which is somehow affected by the action (Gurevich 2006, 134), or as Hewitt (1995, 170) puts it, "When the subject is acting upon himself or in his own interests, the context is such as to trigger the Subjective Version." In typological terms, the core meaning of the Subject Version corresponds quite well to what has been described as the indirect middle/reflexive in the previous sections, including the corresponding functions of the Lithuanian Reflexive marker. Unlike the Lithuanian Reflexive marker, the Georgian Subject Version cannot occur as a direct reflexive/middle marker when used alone, though it can co-occur with the reflexive marker tavs 'oneself'. The most typical use of the subjective version marker looks as follows:

(19) $\mathrm{Me}$ saxl-s $\quad v$-i-šen-eb. I.NOM house-DAT 1SUBJ-VERS-build-THEM 'I build a house for myself.' (Gurevich 2006, 135)

In this sentence, by adding the $-i$ - to the verb, the speaker marks the action as being conducted to his/her own benefit. However, what interests us about the behavior of the Georgian $-i$ - is that with some verbs, the use of $-i$ - in the Aorist (= perfective past), the Future (always marked as perfective in Georgian), and the Optative ${ }^{11}$ is obligatory, whereas it is omitted in the present (in the cases of agent-beneficiary co-reference). I am not aware of studies dedicated specifically to this issue. Grammars of Georgian such as Hewitt $(1995,339-363)$ mention the so-called 'middle/medial verbs'. This is a big class of mostly intransitive verbs which build the aforementioned forms by means of adding a subjective version marker without a preverb. A typical example of such verb is - $t$ 'ir- 'cry':

(20) -t'ir- 'cry': version

$\begin{array}{lllll}\text { PRS: } & v \text { - } & t^{\prime} i r- & i & \\ & \text { 1SG.SUBJ- } & \text { cry- } & \text { THEM } & \\ & \text { 'I am crying' } & & & \\ \text { IMPF: } & v- & t^{\prime} i r- & o- & d i \\ & \text { 1SG.SUBJ- } & \text { cry- } & \text { THEM } & \text { IMPF } \\ & \text { 'I was crying' } & & & \end{array}$

${ }^{11}$ The "optative" of the traditional Georgian grammar corresponds to the subjunctive of the typological use. Its main function is the marking of complement verbs of volitional, deontic, and phase-marking verbs. 


\begin{tabular}{|c|c|c|c|c|}
\hline \multirow[t]{2}{*}{ FUT: } & $v-$ & $i-$ & $t^{\prime}$ ir- & $e b$ \\
\hline & $\begin{array}{l}\text { 1SG.SUBJ- } \\
\text { 'I will cry', }\end{array}$ & VERS & cry- & THEM \\
\hline \multirow[t]{2}{*}{ AOR: } & $v-$ & $i-$ & $t^{\prime} i r_{-}$ & $e$ \\
\hline & $\begin{array}{l}\text { 1SG.SUBJ- } \\
\text { 'I cried' }\end{array}$ & VERS & cry- & AOR \\
\hline \multirow[t]{2}{*}{ OPT: } & $m-i-n d a$ & & \multicolumn{2}{|c|}{$v-\boldsymbol{i}-t^{\prime} i r-o$} \\
\hline & \multicolumn{2}{|c|}{$\begin{array}{l}\text { 1SG.OBJ-VERS-want } \\
\text { 'I want to cry' }\end{array}$} & \multicolumn{2}{|c|}{ 1SG.SUBJ-VERS-cry-OPT } \\
\hline
\end{tabular}

The explanation typically proposed for such use of the subjective series marker is purely diachronic (paradigm merger), which I will not discuss in detail here (see Hewitt 1995, 240). However, one can argue that verbs like 'cry', as well as many others such as -cek'v- 'dance' or -cux- 'be upset', which also belong to this category, presuppose a degree of affectedness of the subject, which is strengthened by the subjective version marker in the listed forms.

Besides the 'medial' verbs, there is a number of transitive verbs exhibiting a similar pattern, in which, however, the marker of version in the same forms co-occurs with preverbs. The formation of the corresponding TAM forms of such verbs belongs to the lexical information about them and is mentioned in dictionaries. Examples of such verbs are - $k$ ' $i t x$ - 'read' and -qid- 'buy':

\begin{tabular}{|c|c|c|c|c|c|}
\hline \multicolumn{3}{|c|}{-k'itx- 'read': preverb + version } & \\
\hline \multirow[t]{2}{*}{ PRS: } & $v-$ & k'itx- & \\
\hline & $\begin{array}{l}\text { 1sG.SUBJ- } \\
\text { 'I am reading' }\end{array}$ & read- & \multicolumn{3}{|c|}{ THEM-THEM } \\
\hline IMPF: & $\begin{array}{l}v- \\
\text { 1sG.SUBJ- } \\
\text { 'I was reading }\end{array}$ & $\begin{array}{l}k^{\prime} i t x- \\
\text { read- }\end{array}$ & \multicolumn{2}{|c|}{$\begin{array}{l}u l-o b- \\
\text { THEM-THEM }\end{array}$} & $\begin{array}{l}d i \\
\text { IMPF }\end{array}$ \\
\hline \multirow[t]{2}{*}{ FUT: } & $c^{\prime} a_{-}^{-}$ & $v-$ & $i-$ & $k^{\prime} i t x-$ & av \\
\hline & $\begin{array}{l}\text { PVB- } \\
\text { 'I will read' }\end{array}$ & 1SG.SUBJ- & VERS & read- & THEM \\
\hline \multirow[t]{2}{*}{ AOR: } & $c^{\prime} a^{-}$ & $v-$ & $i-$ & $k^{\prime} i t x-$ & $e$ \\
\hline & PVB- & 1SG.SUBJ- & VERS & read- & AOR \\
\hline
\end{tabular}




\begin{tabular}{|c|c|c|c|}
\hline OPT: & $m-i-n d a$ & $c^{\prime} a-$ & $v-\boldsymbol{i}-k^{\prime} i t x-o$ \\
\hline & $\begin{array}{l}\text { 1SG.OBJ-VERS-want } \\
\text { 'I want to read' }\end{array}$ & PVB- & 1SG.SUBJ-VERS-read-OPT \\
\hline
\end{tabular}

(22) -q'id- 'buy': version only

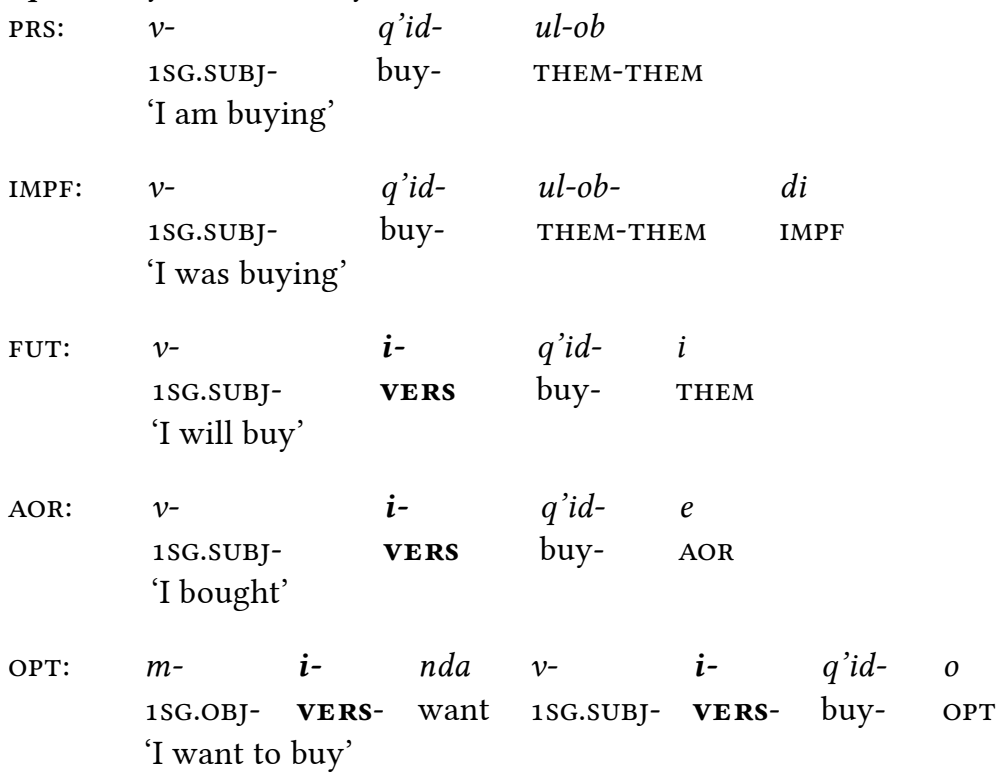

Note that the corresponding verbs in Lithuanian also exhibit a Reflexive autobenefactive marking which is asymmetrical and is blocked in progressive contexts:
(23) (a) $A \check{s}$
skait-au- ${ }^{*}$ si
$k n y g-a$
I.NOM read-PRS.1SG- ${ }^{*}$ REFL book-SG.ACC
'I am reading a book'
(b) $A \check{s}$
pa-si-skaiči-au
knyg-a
I.NOM PVB-REFL-read-PST.1SG book-SG.ACC
'I read a book (a fragment thereof / for a while)'

For examples with pirkti 'buy', see section 3.1. The Intransitive verb verkti 'cry' can have a Reflexive marker in its inchoative, thus perfective forms (ap-si-verkti etc.), and the Georgian verb -cek'v- 'dance' finds its indirect parallel in pa-si-vaikščioti 'go for a walk': both verbs denote a non-directional motion which affects the subject to a certain degree. Note that as in Lithuanian, in Georgian a telic stem is often formed by adding a spatial preverb as in (20), which co-occurs with the subjective 
version marker. The Future stem is always marked as telic in Georgian, i.e., a preverb is added whenever lexically possible, which obligatorily co-occurs with the subject version in some verbs. Summing up, the coding of indirect middle/reflexive meanings in Georgian exhibits striking parallels with Lithuanian regarding actionality-related asymmetries, at least with some verbs.

Although the present comparison with Georgian is very rough and preliminary, the provided data appear sufficient to claim that Lithuanian coding asymmetry is not typologically unique, although parallel phenomena, to my knowledge, have not yet been consistently described for other languages.

\subsection{Indirect middle/reflexive markers as bounders}

In this final section, I propose a preliminary hypothesis about the causes of the phenomenon described above for Lithuanian, which apparently has a cross-linguistic manifestation as well. In the vast field of studies of aspect and actionality/Aktionsart, especially in Slavic, Baltic, and Germanic languages, scholars have long observed that the telic meaning of attainment of a limit ${ }^{12}$ is closely related to spatial semantics, namely, to the meaning of attainment of a physical boundary in the process of motion. That is why such elements as bound preverbs or free spatial adverbs come to function as markers of telicity and, ultimately, perfective aspect in many languages. In their influential work (1989), Bybee and Dahl propose a cover term 'bounders' to define all elements of this type; however, they do not provide a precise definition thereof. They describe the phenomenon as follows:

Adding a bounder to a verb often has effects both on its syntactic valency and its aspectual potential or Aktionsart. Thus, eat up in English differs from the simple eat both by being more clearly transitive and by implying a definite limit or end-state of the process (the total consumption of the object). (Bybee \& Dahl 1989, 86)

The notion of 'bounders' roughly corresponds to Talmy's (1991) notion of 'satellites'. Bounders or satellites, which function primarily with motion verbs, where they exhibit their original path meanings, start to be used

\footnotetext{
${ }^{12}$ A term due to Bybee et al. $(1994,87)$.
} 
with a broader set of verbs. During the course of this process, events in time come to be conceptualized as motion in space, and the former marker of a physical boundary starts to code the limit in time, thus contributing to the event's telicization.

My argument here is that the markers of indirect middle/reflexive in different languages are not unlike bounders and satellites. Though in their original meaning they are devices coding argument structure, the beneficiary or recipient argument they mark (which coincides with the agent) is very much like the endpoint marked by bounders/satellites. Thus, in a situation of buying, the beneficiary/recipient of the action is also a sort of physical endpoint: buying entails taking an object and displacing it toward the point where the buyer is physically located.

The relationship between spatial categories, especially deixis, and argument marking, pronouns in particular, is well known in typology and grammaticalization studies, although, to my knowledge, no overview work on this topic exists. ${ }^{13}$ For instance, the origin of the Italian clitic object pronouns $c i$ 'us' and $v i$ 'you.PL' is widely agreed to be the deictic adverbs meaning 'here' and 'there', respectively. ${ }^{14}$ In colloquial Russian, the deictic adverb 'here' often functions in a way reminiscent of a 1SG pronoun:
(24) Daj sjuda!
give.IMP.2SG here
'Give it (to me)!'

Interestingly, the only possible reading of (24) is the one provided here; readings with a 3 rd or 2 nd person recipient are excluded.

Thus, the hypothesis of the pseudo-spatial conceptualization of the indirect middle/reflexive in Lithuanian, which results in actionalityrelated restrictions and is reminiscent of the functioning of preverbs, is in agreement with well-known general tendencies of grammaticalization. The crucial peculiarity of the phenomenon under discussion is that in our case, spatial meanings seem to derive from the meaning of beneficiary/ recipient argument rather than vice versa. Another example to support this hypothesis is the Lithuanian verb pa-si-kviesti 'invite to one's place',

\footnotetext{
${ }^{13}$ However, see Heine \& Song (2011).

${ }^{14}$ https://www.etimo.it
} 
as well as its Georgian structural counterpart -i-c'vev- ${ }^{15}$ which is marked by a subjective version prefix: in both cases, the readings of the indirect Middle/Reflexive markers are clearly spatial.

This is a preliminary hypothesis, grounded in a relatively modest set of empirical data. Its more solid verification needs further large-scale cross-linguistic investigation.

\section{Conclusion}

In this paper, I have investigated the domain of the indirect reflexive/ middle in Lithuanian. I have proposed a classification of semantic types occurring in this domain. I argue that it makes sense to distinguish between the Strong Autobenefactive, the Weak Autobenefactive, the Possessive Reflexive, and the Reflexive Recipient (Section 2) based on compatibility properties of the verbs. Additionally, I show that in the whole domain of indirect middle/reflexive, there is a weak tendency for verbs marked in this way to occur in telic contexts exclusively, e.g., being ungrammatical in the progressive Present; this is an ongoing grammaticalization process in contemporary Lithuanian, and grammaticality judgements for different verbs vary between speakers. However, some verbs exhibit a relatively consistent behavior in this respect. This coding asymmetry is not unique to Lithuanian: a very similar phenomenon occurs in Georgian. I propose an explanatory hypothesis for this asymmetry. In my view, the markers of indirect middle/reflexive in Lithuanian and other languages function in a way similar to preverbs and other kinds of 'bounders' or 'satellites' with respect to the effect they have upon the actionality characteristics of a situation. Like the latter, the beneficiary or recipient argument is conceptualized as a physical endpoint of the action, which sometimes presupposes a physical displacement of objects, as in the case of the verb 'buy'.

Verifying the proposed hypothesis requires a large-scale cross-linguistic investigation of the coding asymmetry in question.

\footnotetext{
${ }^{15}$ I wish to thank thank an anonymous reviewer for this example.
} 


\section{AbBreviations}

ACC - accusative, AOR - aorist, NOM - nominative, DAT - dative, FUT future, GEN - genitive, HAB - habitual, IMP - imperative, IMPF - imperfect, INF - infinitive, INS - instrumental, IPFV - imperfective, LOC - locative, OBJ - object, OPT - optative, PFV - perfective, PL - plural, PRS - present, PVB - preverb, PST - past, REFL - reflexive, SG - singular, sUBJ - subject, THEM - thematic extension, vERs - version

\section{REFERENCES}

Allan, Rutger J. 2003. The Middle Voice in Ancient Greek: A Study in Polysemy (Amsterdam Studies in Classical Philology, 11). Amsterdam: J. C. Gieben.

Arkadiev, Peter M. 2011. Aspect and actionality in Lithuanian on a typological background. In: Daniel Petit, Claire Le Feuvre \& Henri Menantaud, eds., Langues baltiques, langues slaves. Paris: Éditions CNRs, 57-86.

Boeder, Winfried. 1968. Über die Versionen des georgischen Verbs. Folia Linguistica 2.1-2, 82-152.

Bybee, Joan L. \& Ósten Dahl. 1989. The creation of tense and aspect systems in the languages of the World. Studies in Language 13.1, 51-103.

Bybee, Joan L., Revere D. Perkins \& William Pagliuca. 1994. The Evolution of Grammar: Tense, Aspect, and Modality in the Languages of the World. Chicago: University of Chicago Press.

Croft, William. 2001. Radical Construction Grammar: Syntactic Theory in Typological Perspective. Oxford: Oxford University Press.

Dom, Sebastian, Leonid Kulikov \& Koen Bostoen. 2016. The middle as a voice category in Bantu: Setting the stage for further research. Lingua Posnaniensis 58.2, 129-149.

Geniušiené, Emma. 1987. The Typology of Reflexives. Berlin-New York: Mouton de Gruyter.

Gurevich, Olga I. 2006. Constructional Morphology: The Georgian Version. $\mathrm{PhD}$ thesis. Berkeley: University of California.

Harris, Alice C. 1981. Georgian Syntax: A Study in Relational Grammar. Cambridge-New York: Cambridge University Press.

Haspelmath, Martin. 2010. Comparative concepts and descriptive categories in crosslinguistic studies. Language 86.3, 663-687. 
Haspelmath, Martin. 2018. How comparative concepts and descriptive linguistic categories are different. In: Daniël van Olmen, Tanja Mortelmans \& Frank Brisard, eds., Aspects of Linguistic Variation. Berlin-Boston: Mouton de Gruyter, 83-113.

Heine, Bernd \& Kyung-An Song. 2011. On the grammaticalization of personal pronouns. Journal of Linguistics 47.3. 587-630.

Hewitt, George. 1995. Georgian: A Structural Reference Grammar (London Oriental and African Language Library, 2). Amsterdam: John Benjamins.

Holvoet, Axel. 2020. The Middle Voice in Baltic. Amsterdam: John Benjamins.

Hopper, Paul J. \& Sandra A. Thompson. 1980. Transitivity in grammar and discourse. Language 56.2, 251.

JACQues, Guillaume. 2015. The spontaneous-autobenefactive prefix in Japhug Rgyalrong. Linguistics of the Tibeto-Burman Area 38.2, 271-291.

Kemmer, Suzanne. 1993. The Middle Voice. Amsterdam: John Benjamins.

Kulikov, Leonid. 2013. Middle and Reflexive. In: Silvia Luraghi \& Claudia Parodi, eds., The Bloomsbury Companion to Syntax. London-New York: Bloomsbury Academic, 261-280.

Schmidtke-Bode, Karsten, Natalia Levshina, Susanne Maria Michaelis \& Ilja A. SeržAnt. 2019. Explanation in Typology: Diachronic Sources, Functional Motivations and the Nature of the Evidence. Berlin: Language Science Press.

Talmy, Leonard. 1991. Path to realization: A typology of event conflation. Annual Meeting of the Berkeley Linguistics Society 17.1, 480-519.

Tomelleri, Vittorio S. \& Manana Topadze Gäumann. 2015. Aspectual pairs in Georgian: Some questions. STUF-Language Typology and Universals $68.1,49-85$.

TOMelleri, Vittorio Springfield. 2009. The Category of Aspect in Georgian, Ossetic and Russian. Some areal and typological observations. Faits de Langues 34.2, 245-272.

Tsunoda, TASAKU. 1981. Split case-marking patterns in verb-types and tense/aspect/mood. Linguistics 19.5-6, 389-438.

Willi, Andreas. 2018. Origins of the Greek Verb. Cambridge: Cambridge University Press. 


\section{Appendix: The Questionnaire}

The questionnaire contains indirect middle/reflexive verbs established in the stage of participant observation. My informants were asked the question: would you use the constructions given below with the adverb dabar 'now'? Verbs are given with and without a Reflexive marker, some are also given in a form with a preverb and without. When there is no significant difference in meaning, only one translation is provided. Every English translation implies that the action is performed for the benefit of the speaker. For each verb, the number of informants who gave each kind of answer is indicated; empty cells are to be interpreted as 'zero'.

\begin{tabular}{|c|c|c|c|}
\hline & $\begin{array}{l}\text { I would } \\
\text { definitely } \\
\text { say this }\end{array}$ & $\begin{array}{l}\text { I could } \\
\text { probably } \\
\text { say this, } \\
\text { but it is } \\
\text { unlikely }\end{array}$ & $\begin{array}{l}\text { I would } \\
\text { definitely } \\
\text { not say } \\
\text { this }\end{array}$ \\
\hline perkuosi duona / duonos & & 1 & 4 \\
\hline perku (sau) duonq / duonos & & & \\
\hline 'I am buying bread' & 5 & & \\
\hline imuosi puoduka iš spintos & & & 5 \\
\hline imu (sau) puoduka iš spintos & & & \\
\hline 'I am taking a cup from the cupboard' & 5 & & \\
\hline deduosi buteli i kuprine & 5 & & \\
\hline dedu buteli (sau) i kuprinę & & & \\
\hline 'I am putting a bottle into (my) rucksack' & 3 & 1 & 1 \\
\hline deduosi (savo) tušinuka ant stalo & 1 & 2 & 2 \\
\hline dedu (savo) tušinuka ant stalo & & & \\
\hline 'I am putting the pencil on the table' & 5 & & \\
\hline darausi pietus & 4 & 1 & \\
\hline darau (sau) pietus & & & \\
\hline 'I am making lunch' & 2 & 1 & 2 \\
\hline gaminuosi pietus & 3 & 2 & \\
\hline
\end{tabular}




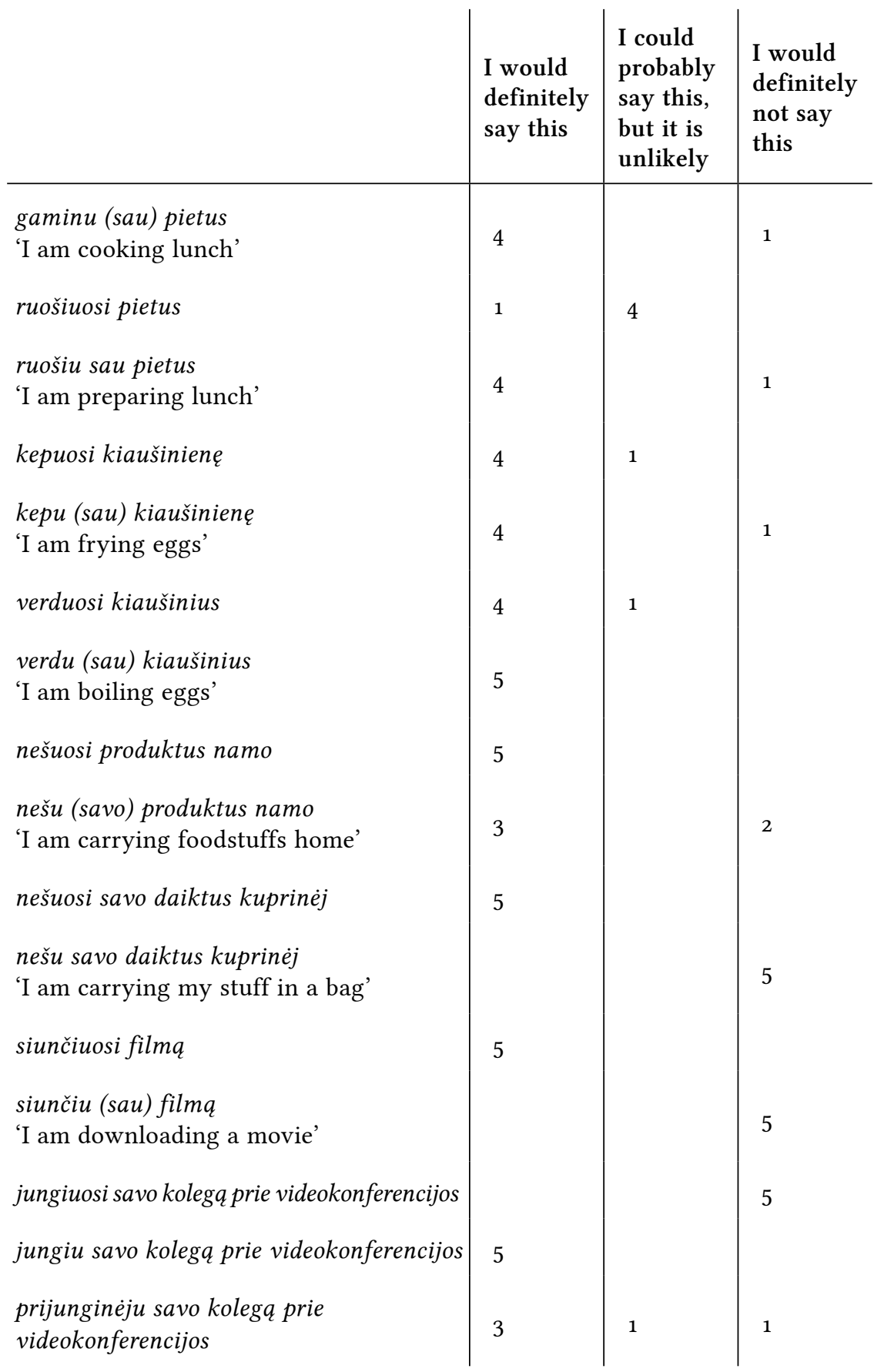




\begin{tabular}{|c|c|c|c|}
\hline & $\begin{array}{l}\text { I would } \\
\text { definitely } \\
\text { say this }\end{array}$ & $\begin{array}{l}\text { I could } \\
\text { probably } \\
\text { say this, } \\
\text { but it is } \\
\text { unlikely }\end{array}$ & $\begin{array}{l}\text { I would } \\
\text { definitely } \\
\text { not say } \\
\text { this }\end{array}$ \\
\hline $\begin{array}{l}\text { prisiungineju savo kolega prie videokon- } \\
\text { ferencijos } \\
\text { 'I am making my colleague join the } \\
\text { video conference' }\end{array}$ & & & 5 \\
\hline $\begin{array}{l}\text { nusiraš-au/-inèju nuo suolo draugo } \\
\text { nurašau/nurašinèju nuo suolo draugo } \\
\text { 'I am copying from my desk mate' }\end{array}$ & 5 & & 5 \\
\hline ieškausi buto & 5 & & \\
\hline $\begin{array}{l}\text { ieškau (sau) buto } \\
\text { 'I am looking for a flat' }\end{array}$ & 3 & & 2 \\
\hline $\begin{array}{l}\text { deduosi daiktus i kelionę } \\
\text { dedu daiktus i kelione (važiuoju pats) } \\
\text { 'I am packing stuff for a journey' }\end{array}$ & 5 & 2 & 3 \\
\hline pasižymiu svarbius punktus & 5 & & \\
\hline žymiuosi svarbius punktus & 4 & 1 & \\
\hline $\begin{array}{l}\text { pažymiu (sau) svarbius punktus } \\
\text { 'I am marking important points' }\end{array}$ & 4 & 1 & \\
\hline vežuosi daug savo daiktų namo & 5 & & \\
\hline $\begin{array}{l}\text { vežu daug savo daiktu namo } \\
\text { 'I am taking a lot of my stuff home (by car)' }\end{array}$ & 4 & & 1 \\
\hline kalbuosi su draugu & 5 & & \\
\hline $\begin{array}{l}\text { kalbu su draugu } \\
\text { 'I am talking to a friend' }\end{array}$ & 4 & & 1 \\
\hline $\begin{array}{l}\text { tariuosi su draugu } \\
\text { 'I am getting advice from my friend' }\end{array}$ & 5 & & \\
\hline vaikščiojuosi po parka & & & 5 \\
\hline
\end{tabular}




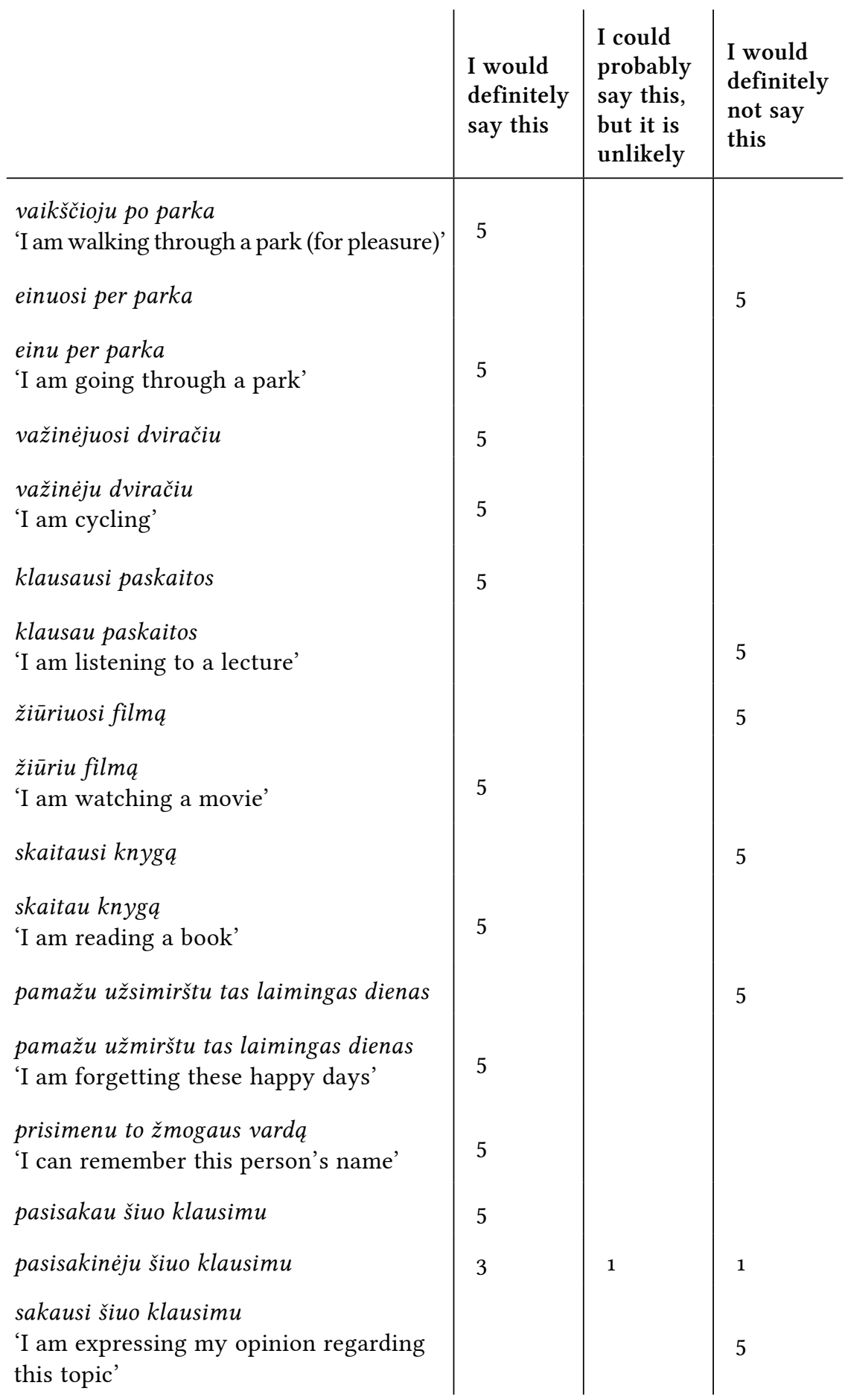




\begin{tabular}{|c|c|c|c|}
\hline & $\begin{array}{l}\text { I would } \\
\text { definitely } \\
\text { say this }\end{array}$ & $\begin{array}{l}\text { I could } \\
\text { probably } \\
\text { say this, } \\
\text { but it is } \\
\text { unlikely }\end{array}$ & $\begin{array}{l}\text { I would } \\
\text { definitely } \\
\text { not say } \\
\text { this }\end{array}$ \\
\hline plaunuosi rankas & 5 & & \\
\hline plaunu rankas (sau) & & & \\
\hline 'I am washing my hands' & 4 & 1 & \\
\hline skutuosi galva & 5 & & \\
\hline skutu sau galva & & & \\
\hline 'I am shaving my head' & 3 & 1 & 1 \\
\hline kerpuosi nagus & 5 & & \\
\hline kerpu (sau) nagus & & & \\
\hline 'I am cutting my nails' & 3 & 1 & 1 \\
\hline valausi veida & 5 & & \\
\hline valau (sau) veida & & & \\
\hline 'I am washing my face' & 3 & 1 & 1 \\
\hline laužausi ranka (e.g., kad išvengčiau & & & \\
\hline $\begin{array}{l}\text { kariuomenès šaukimo) } \\
\text { 'I am breaking my arm (e.g., to avoid } \\
\text { military service)' }\end{array}$ & 5 & & \\
\hline kasausi rankq & 5 & & \\
\hline kasau (sau) ranka & & & \\
\hline 'I am scratching my arm' & 3 & 1 & 1 \\
\hline $\begin{array}{l}\text { gadinuosi notaika (pvz., skaitydama(s) } \\
\text { per daug naujienu) }\end{array}$ & 5 & & \\
\hline gadinu sau nuotaikta & & & \\
\hline $\begin{array}{l}\text { 'I am spoiling my mood (e.g., by reading } \\
\text { the news)' }\end{array}$ & 3 & 2 & \\
\hline rengiuosi marškinius & 5 & & \\
\hline $\begin{array}{l}\text { rengiu (sau) marškinius } \\
\text { 'I am putting on my shirt' }\end{array}$ & & & 5 \\
\hline
\end{tabular}




\begin{tabular}{|c|c|c|c|}
\hline & $\begin{array}{l}\text { I would } \\
\text { definitely } \\
\text { say this }\end{array}$ & $\begin{array}{l}\text { I could } \\
\text { probably } \\
\text { say this, } \\
\text { but it is } \\
\text { unlikely }\end{array}$ & $\begin{array}{l}\text { I would } \\
\text { definitely } \\
\text { not say } \\
\text { this }\end{array}$ \\
\hline deduosi kepurę & 5 & & \\
\hline dedu (sau) kepure & & & \\
\hline 'I am putting on my hat' & & & 5 \\
\hline aunuosi batus & 5 & & \\
\hline aunu (sau) batus & & & \\
\hline 'I am putting on my shoes' & & & 5 \\
\hline maunuosi pirštines & 5 & & \\
\hline maunu (sau) pirštines & & & \\
\hline 'I am putting on gloves' & & & 5 \\
\hline velkuosi palta & 5 & & \\
\hline velku (sau) palta & & & \\
\hline 'I am putting on a coat' & & & 5 \\
\hline atsigulu į lova & 5 & & \\
\hline guluosi i lova & & & \\
\hline 'I am lying down on the bed' & 5 & & \\
\hline atsisèdu $i$ kèdę & 4 & & 1 \\
\hline sèduosi į kèdę & & & \\
\hline 'I am sitting down in /on the chair' & 5 & & \\
\hline atsistoju iš kèdès & 5 & & \\
\hline stojuosi iš kèdès & & & \\
\hline 'I am standing up from the chair' & 4 & & 1 \\
\hline
\end{tabular}

\section{Vladimir Panov}

Vilnius University

Institute for the Languages and Cultures of the Baltic

Universiteto 5

LT-o1131 Vilnius

vladimir.panov@flf.vu.lt 